\title{
Effect of safety climate on safety behavior in employees: The mediation of safety motivation
}

\author{
Ariska Nurul Heryati, ${ }^{1}$ Rini Nurahaju, ${ }^{2 *}$ Gartinia Nurcholis, ${ }^{3}$ Firmanto Adi Nurcahyo ${ }^{4}$ \\ 1,2,3 Faculty of Psychology, Universitas Hang Tuah, Surabaya - Indonesia, ${ }^{4}$ Faculty of Psychology, Universitas \\ Pelita Harapan, Surabaya - Indonesia
}

\begin{abstract}
The number of work accidents in production employees is high. One reason is the lack of compliance of employees with workplace safety rules. The necessary aspects that can improve workplace safety are safety climate and safety motivation. The purpose of this study was to examine the effect of safety climate on safety behavior both directly and indirectly mediated by safety motivation. Three scales were used in this study, namely the safety behavior scale, the safety climate scale, and the safety motivation scale. The Cronbach's Alpha coefficients were 0.898 , 0.922 , and 0.896 . The respondents were 78 employees in the production, processing, and quality assurance section. Data were analyzed using regression analysis. The result showed the direct effect $(\beta=0.272)$ and the indirect effect of safety climate on safety behavior $(\beta=0.281)$. The effect of climate safety on safety behavior was partially mediated by safety motivation.
\end{abstract}

Keywords: safety behavior; safety climate; safety motivation

\begin{abstract}
Abstrak: Jumlah kecelakaan kerja pada karyawan produksi tinggi. Salah satu alasannya adalah kurangnya kepatuhan karyawan pada aturan keselamatan di tempat kerja. Aspek yang diperlukan yang dapat meningkatkan keselamatan di tempat kerja adalah iklim keselamatan dan motivasi keselamatan. Tujuan penelitian ini adalah untuk menguji pengaruh iklim keselamatan pada perilaku keselamatan baik secara langsung maupun tidak langsung yang dimediasi oleh motivasi keselamatan. Tiga skala yang digunakan dalam penelitian ini, yaitu skala perilaku keselamatan, skala iklim keselamatan, dan skala motivasi keselamatan. Koefisien Alpha Cronbach adalah 0,898, 0,922, dan 0,896. Responden adalah 78 karyawan di bagian produksi, pengolahan, dan kualitas. Data dianalisis menggunakan analisis regresi. Hasil penelitian menunjukkan efek langsung $(\beta=0,272)$ dan efek tidak langsung iklim keselamatan pada perilaku keselamatan $(\beta=0,281)$. Efek keselamatan iklim terhadap perilaku keselamatan sebagian dimediasi oleh motivasi keselamatan.
\end{abstract}

Kata Kunci: perilaku aman; iklim keselamatan; motivasi keselamatan

\footnotetext{
*Corresponding Author: Rini Nurahaju (e-mail rini.nurahaju@hangtuah.ac.id), Faculty of Psychology, Universitas Hang Tuah, Jl. Arif Rahman Hakim No. 150 Surabaya 60111, Indonesia.
} 


\section{Introduction}

Achieving the industry's best result cannot be separated from the role of Human Resources (HR) as an important factor. To obtain a workforce that supports the achievement of industrial objectives, the industry must conduct a good management, especially with Occupational Health and Safety (OHS) which aims to maintain the survival of the employees and the industry.

Based on data from the Social Security Administrator (SSA/BPJS), the number of work accidents has increased high. In 2017 the number of reported work accidents was 123,041 cases, while in 2018 it reached 173,105 cases. Every year the average Social Security Administrator for Employment serves 130 thousand cases of work accidents from minor cases to fatal cases. Generally, cases handled are still dominated by cases of minor work accidents in the work environment in the factory (BPJS News Team, 2019). Data obtained from the International Labor Organization (ILO) showed that every 15 seconds, 153 workers die due to work accidents. Every day, 6,300 people die as a result of workplace accidents or work-related diseases (Safety Sign Indonesia, 2015).

According to Dessler (2005) the occurrence of work accidents is influenced by two direct causes, i.e., unsafe behavior and unsafe conditions. It was supported by the result of the research of the National Safety Council (NSC) in 2011 that the causes of workplace accidents are $88 \%$ due to unsafe behavior, $10 \%$ due to unsafe conditions, and $2 \%$ due to unknown causes (Ningsih \& Wahyudiono, 2013).

Kavianian and Wentz (1990) indicated that unsafe behavior is an unsafe acts caused by human negligence, such as not using Personal Protective Equipment (PPE) in working, disposing of objects carelessly and not complying with work procedures. Employee behavior at work is a factor that influences work accidents. An effective way to prevent work accidents is to avoid unsafe behavior (Budiono, 2003). To change the unsafe behavior into the safe behavior is the responsibility of the company and the employees.

Sujadiyanto (2017) explained that one of the efforts made to prevent occupational accidents is to perform safety behavior. Bird and Germain (1996) explained that safety behavior is a behavior that does not cause an accident or incident. According to Heinrich (1980) safety behavior is the action of a person or several employees who minimize the possibility of accidents to employees. Griffin, Neal, and Neale (2000) argued that safety behavior is safetyoriented behavior that is applied in daily work.

Work accidents need to be avoided for it can have a negative impact on the company. Therefore, the Occupational Health and Safety Management System (OHSMS) must be implemented consistently according to the law. One company that has received OHSMS certification is Sugar Factory Kremboong Sidoarjo which is a company producing white crystal sugar.

The result of the interview with the Human Resources at the Krembong Sugar Factory Sidoarjo showed that in the last month, three work accidents have occurred. The accident was due to careless work, less attention to safety behaviors such as lack of compliance with safety procedures and not wearing Personal Protective Equipment (PPE). The result of the observation also showed that some employees did not comply with the existing procedures, such as there are employees who do not walk on the specified track, and some employees do not use PPE in full.

Pre-research was conducted on 20 respondents in the installation, processing and quality 
assurance of the Kremboong Sugar Factory Sidoarjo. The result indicated that 8 employees (40\%) have a high tendency for safety behavior, and 12 employees (60\%) have low safety behavior. In general the safety behavior of the employees is relatively low. Therefore, the problem of the employee's safety behavior at Kremboong Sugar Factory Sidoarjo needs to be studied.

Neal and Griffin (2006) stated that safety behavior consists of two dimensions of safety, i.e., compliance and safety participation. Safety compliance refers to the main activities that individuals need to do to maintain security in the work environment. This is reflected in the form of behavior that follows the standard rules of work procedures and uses Personal Protective Equipment (PPE). Safety participation is the desire of employees to actively improve safety behavior in the work environment. It is demonstrated by volunteering in occupational safety activities, helping co-workers on issues related to work safety, and attending work safety meetings.

According to Neal and Griffin (in Setiawan \& Agustina, 2014) there are two factors that influence safety behavior, namely the individual and the work environment. Commitment, individual differences (accuracy and motivation), personality (individuals who are prone to accidents) are examples of individual factor. The work environment factor consists of safety climate and organizational factors such as supervisors and job design.

Related to the safety climate, the company seeks to create a good working atmosphere or organizational climate in order to produce the desired behavior so that it can lead to the success of the company. Zohar (2003) stated that perceptions of safety climate illustrate employee confidence in safety priorities and these perceptions indicate expectations of behavioral outcomes.
According to Neal and Griffin (2002), safety climate refers to perceptions regarding policies, procedures, and implementation relating to safety in the workplace. Meanwhile, Hofmann and Stetzer (1996) stated that a positive work safety climate has a high correlation with harmless behavior at work.

Griffin et al., (2000) measure the safety climate which consists of five systems, namely management value, safety communication, safety practices, safety training, and safety equipment. Management value shows how far the manager values safety at work; this includes the company management's attitude to safety and the company management's perception of how important safety is. Safety communication is communication related to safety issues. Safety practices are related to programs implemented by the company management which aim to improve employee safety. Safety training includes trainings designed to ensure an adequate level of safety in the organization. Safety equipment is related to the adequacy of the available safety equipment.

The consideration that must be made in the management of work safety is to create a positive workplace safety climate, in which there must be a strong commitment to safety work on the managerial side. These commitments include strengthening work safety training programs, giving high status to occupational safety officials, participating in the top executive ranks in the work safety committee, and designing work that is based on work safety.

Based on his study, Taqwa (2017) explained that to improve safety climate can be done by implementing more intense programs in the field of occupational safety and health. It includes conducting training, posting posters through words that are easy to understand, and designing safe and confortable room for employees. 
Hoffman and Morgeson (in Neal \& Griffin, 2006) indicated that employees who perceive their organizations are very concerned about work safety exhibiting compliance behavior with safety procedures, in the condition of safety motivation as the mediator. In other words, safety behavior is not only influenced by climate work safety, but employee safety motivation is needed in improving the behavior.

The result of Sulistiobudi and Kadiyono (2017) indicated that motivation plays an important role in achieving goals. This is known as motivational climate which is defined by Arnes (in Sulistiobudi \& Kadiyono, 2017) as the extent of individual's perception of expectations regarding a motivating situation, thereby arousing a certain orientation towards goals and at the same time stimulates the emergence of the involvement in the goal. Neal and Griffin (2006) asserted that safety motivation mediates the relationship between safety work climate and safety behavior.

Hofmann (in Probst \& Brubaker, 2001) defined safety motivation as employee motivation to carry out the work safely and harmlessly. Neal (in Probst \& Brubaker, 2001) stated safety motivation as motivation to perform safety behavior. Neal and Griffin (2006) explained that the term safety motivation refers to the individual's willingness to exert every effort to carry out safety behaviors.

Griffin et al. (2000) stated that the measurement of safety motivation can be conducted based on two dimensions, i.e., compliance motivation and participation motivation. Compliance motivation is the drive to perform the importance tasks related to safety. Participation motivation is the encouragement to participate in the activities that support the safety in the organization.

There are several things that can increase employee's safety motivation. Siagian (in Vitri, 2003) stated that the provision of positive reinforcement by supervisors can increase employee's safety motivation. Lingard (2002) indicated that providing first aid training can increase employee motivation to work safely, while Huda, Sukmawati, and Sumertajaya (2016) stated that applying reward and punishment system related to safety can improve employee work motivation.

The previous explanation regarding safety behavior, safety climate, and safety motivation showed that those three variables are positively correlated. Employees are motivated to comply with work safety procedures and to contribute in creating a safe work environment, if they have a positive perception of the work safety climate and the company has more concern regarding their safety (Huda et al., 2016). Furthermore, safety motivation encourages employees to perform safety behaviors to avoid work accidents. Therefore the hypotheses of this study are there is a direct effect of safety climate on safety behavior and there is an indirect effect of safety climate on safety behavior mediated by safety motivation. The research model can be seen in Figure 1.

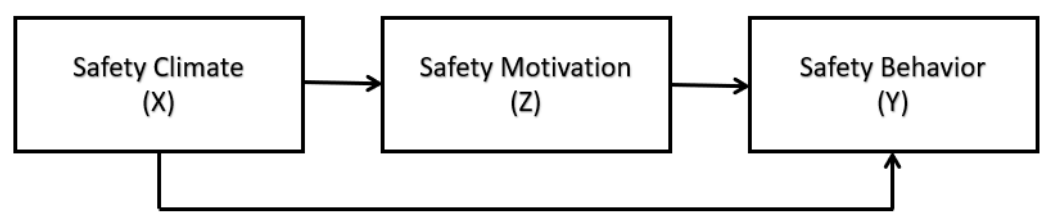

Figure 1.

Research Model 


\section{Method}

The population was 101 production employees in the installation, processing, and quality assurance group III-IV and I-II Kremboong Sugar Factory Sidoarjo. The researcher used an error rate of $5 \%$ so that the sample used in this study was 78 employees. Proportionate stratified random sampling was used as the sampling technique.

This study was conducted with a quantitative approach, data collection was conducted using three scales, i.e., the safety behavior scale, the safety climate scale, and the safety motivation scale. The safety behavior scale consists of 20 items, developed based on two dimensions of safety behavior namely safety compliance and safety participation. The safety climate scale consists of 34 items, developed based on five dimensions of safety climate namely management value, safety communication, safety practices, safety training, and safety equipment. The safety motivation scale consists of 20 items, developed based on two dimensions of safety motivation namely compliance motivation and participation motivation.

The item selection process was conducted based on the item-total correlation coefficient $>0.30$ (Azwar, 2013). Items with a correlation coefficient of $<0.30$ were eliminated for they were considered to have a low discrimination power.

The three scales used in this study were reliable ( $r>0.70)$. The Cronbach's Alpha coefficient for the safety behavior scale with 16 items was 0.898 , the climate safety scale with 27 items was 0.922 , and the safety motivation scale with 17 items was 0.896. To test the direct and indirect effects, the regression analysis was performed with SPSS software.

\section{Results}

The result of safety behavior categorization is shown in Table 1. The highest percentage, which is $40 \%$, lies in the moderate category. $28 \%$ of the subjects were in the high to very high category, while $32 \%$ of the subjects were in the low to very low category.

Table 1.

Safety Behavior Categorization

\begin{tabular}{llll}
\hline Category & Score & F & $(\%)$ \\
\hline Very High & $>71$ & 5 & $6 \%$ \\
High & $63-70$ & 17 & $22 \%$ \\
Moderate & $56-62$ & 31 & $40 \%$ \\
Low & $47-55$ & 22 & $28 \%$ \\
Very Low & $<47$ & 3 & $4 \%$ \\
\hline Total & & 78 & $100 \%$ \\
\hline
\end{tabular}

Table 2.

Safety Climate Categorization

\begin{tabular}{llll}
\hline Category & Score & F & $(\%)$ \\
\hline Very High & $>115$ & 9 & $12 \%$ \\
\hline High & $100-114$ & 12 & $15 \%$ \\
\hline Moderate & $86-99$ & 31 & $40 \%$ \\
\hline Low & $71-85$ & 25 & $32 \%$ \\
\hline Very Low & $<71$ & 1 & $1 \%$ \\
\hline & & 78 & $100 \%$ \\
\hline
\end{tabular}


The result of safety climate categorization is shown in Table 2. The highest percentage, which is $40 \%$, lies in the moderate category. $27 \%$ of the subjects were in the high to very high category, while $33 \%$ of the subjects were in the low to very low category.

The result of safety motivation categorization is shown in Table 3. The highest percentage, which is $38 \%$, lies in the moderate category. $27 \%$ of the subjects were in the high to very high category, while $35 \%$ of the subjects were in the low to very low category.

Intercorrelation analysis was performed to determine whether there was a correlation between each variable. The result of the analysis is shown in Table 4. A significant positive correlation between safety climate and safety behavior was found ( $r=0.552$ ). A significant correlation was also found in the correlation between safety motivation and safety behavior ( $r=0.617$ ), as well as in the correlation between safety climate and safety motivation ( $r=0.629$ ).

The result of the regression analysis is shown in Table 5. The result showed the direct effect $(\beta=$ 0.272 ) and the indirect effect of safety climate on safety behavior $(\beta=0.281)$. The total effect of safety climate on safety behavior is 0.553 . The direct and indirect effect of safety climate on safety behavior mediated by safety motivation can be illustrated in Figure 2.

Table 3.

Safety Motivation Variable Categorization

\begin{tabular}{llll}
\hline Category & Score & $\mathrm{F}$ & $(\%)$ \\
\hline Very High & $>75$ & 4 & $5 \%$ \\
\hline High & $67-75$ & 17 & $22 \%$ \\
\hline Moderate & $57-66$ & 30 & $38 \%$ \\
\hline Low & $48-56$ & 24 & $31 \%$ \\
\hline Very Low & $<48$ & 3 & $4 \%$ \\
\hline Total & & 78 & $100 \%$ \\
\hline
\end{tabular}

Table 4.

Results of Intercorrelation Analysis

\begin{tabular}{ccccccc}
\hline Variable & \multicolumn{2}{c}{ SB } & \multicolumn{2}{c}{ SC } & \multicolumn{2}{c}{ SM } \\
\cline { 2 - 7 } & $\mathrm{r}$ & Sig. & $\mathrm{R}$ & Sig. & $\mathrm{r}$ & Sig. \\
\hline SB & 1 & - & 0,552 & $0.000^{*}$ & 0.617 & $0.000^{*}$ \\
\hline SC & 0.552 & $0.000^{*}$ & 1 & - & 0.629 & $0.000^{*}$ \\
\hline SM & 0.617 & $0.000^{*}$ & 0,629 & $0.000^{*}$ & 1 & - \\
\hline
\end{tabular}

* Significance at $\mathrm{p}<0.05$, Safety Behavior (SB), Safety Climate (SC), and Safety Motivation (SM)

Table 5.

The Result of Analysis of Direct and Indirect Effects

\begin{tabular}{ccccccc}
\hline \multirow{2}{*}{ Variable } & \multicolumn{3}{c}{$\mathrm{M}(\mathrm{SM})$} & \multicolumn{3}{c}{$\mathrm{Y}(\mathrm{SB})$} \\
\cline { 2 - 7 } & $\beta$ & $\mathrm{t}$ & Sig. & $\beta$ & $\mathrm{t}$ & Sig. \\
\hline $\mathrm{X}(\mathrm{SC})$ & 0.629 & 7.047 & $<0.05$ & 0.272 & 2.417 & $<0.05$ \\
$\mathrm{M}(\mathrm{SM})$ & - & - & - & 0.446 & 3.963 & $<0.05$ \\
\hline
\end{tabular}

Direct effect Indirect effect Total effect

0.272

$0.629 \times 0.446=0.281$

$0.272+0.281=0.553$ 


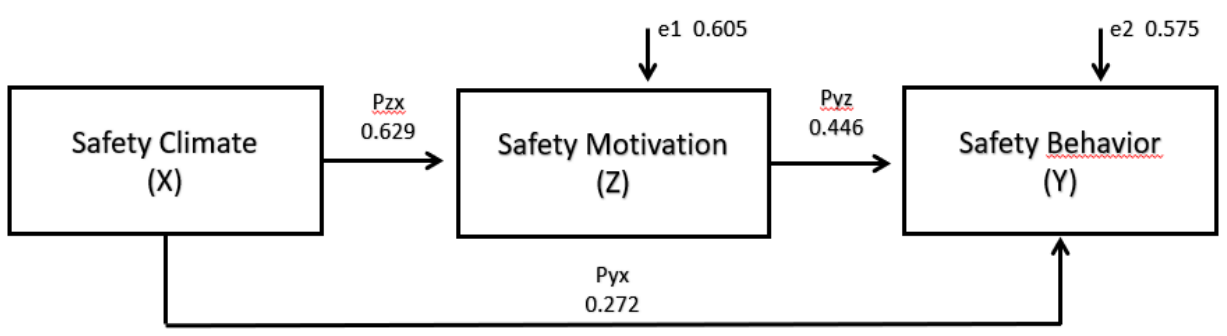

Figure 2.

Result Analysis of Path Diagram

\section{Discussion}

This study attempts to examine the role of safety motivation as a mediating variable, in the effect of climate safety on safety behavior in employees of the Kremboong Sugar Factory Sidoarjo. In this study, the researchers refer to Baron and Kenny (1986) in explaining mediation with regression analysis. There are four conditions that indicate a variable as a mediator, i.e., the independent variable significantly predict the dependent variable, the independent variable significantly predicts the mediator variable, the mediator variable predict the dependent variable, and when the independent variable is added in the regression, it can reduce the level of significance. The complete mediation effect occurs when there is no effect of the independent variable on the dependent variable, under the condition that the mediator variable is controlled. The partial mediation effect occurs when there is a significant effect of the independent variable on the dependent variable and there is a significant mediation.

Based on the result of the analysis it can be concluded that there is a direct effect of the safety climate variable on the safety behavior variable $(\beta$ $=0.272, \mathrm{p}<0.05$ ). This is in line with the research conducted by Neal and Griffin (2002) which stated that various factors in the individual and work environment influence safety behavior, including ability, motivation, personality, safety climate, and organizational factors. Poor safety climate will have an impact on decreasing safety behavior that causes many work accidents (Neal \& Griffin, 2006).

Snyder, Krauss, Chen, Finlinson, and Huang (2008) explained that safety climate is the workers' perceptions of safety practices, regulations, and procedures so that they act safely in the work environment. The management of the companies need to pay attention to the safety climate for it makes employees feel prosperous at work and it directs them to act safely at work

The descriptive analysis result shows that more than $70 \%$ of the respondents perceive the safety climate in the moderate to low category. In other words the majority of employees do not perceive the safety climate in the high category. This is possible due to the incomplete safety facilities at the Kremboong Sugar Factory Sidoarjo.

According to Hofmann and Stetzer (in Winarsunu, 2008) a positive safety work climate has a high correlation with harmless behavior at work. Safety climate shapes the employee perceptions regarding the application of safety in the company. Positive employee perceptions of the work safety climate will improve employee safety behavior at the company. Conversely, 
negative perceptions of the work safety climate cause unsafe behavior, resulting in work accidents which in turn will affect company productivity and can cause harm to the company.

The result of data analysis also showed an indirect effect of the safety climate on the safety behavior, mediated by the safety motivation. Furthermore, the indirect effect $(\beta=0.281)$ was found to be higher than the direct effect $(\beta=0.272)$. This supports the role of safety motivation in mediating safety climate safety and safety behavior.

The result showed both direct and indirect effect of safety climate on safety motivation mediated by safety behavior. According to Baron and Kenny (1986), the effect of climate safety on safety behavior in this study was partially mediated by safety motivation.

Neal and Griffin (2002) defined safety motivation as individual's willingness to direct efforts in implementing safety behavior. According to Vinodkumar and Bhasi (2010), safety motivation is an encouragement of individual to do safety. Employees who have safety motivation will comply with work safety procedures and contribute to a safe work environment.

Neal and Griffin (2006) asserted that safety motivation mediates the relationship between safety work climate and safety behavior. The motivation of employees to behave safely in work will increase with the increasing their perceptions of the work safety climate at work.

The role of safety motivation as a mediator between safety climate and safety behavior needs to be supported by the company management by giving a safety training. The company manage- ment can provide training related to safety work which is carried out at least once in a six months. Probst and Brubaker (2001) found that safety motivation has an effect on safety compliance for about six months.

In the context of social exchange theory, Neal and Griffin (2006) explain that if employees have a perception that the organization cares about good things for employees, they will be motivated to do everything that can benefit the organization. In this study, employees who have a positive safety climate and high safety motivation exhibit high safety behaviors. A positive safety climate will support employees to obey the regulations related to safety in the workplace. Moreover employees who have high safety motivation will tend to do safety behaviors to avoid work accidents.

\section{Conclusion}

The results of this study indicate that there is a direct effect of safety climate on safety behavior. The indirect effect of safety climate on safety behavior mediated by safety motivation was also found. In conclusion, the effect of climate safety on safety behavior was partially mediated by safety motivation.

Based on the result of this study, the company management can develop employee safety behavior by providing a work environment that supports safety climate safety, e.g., providing work safety training and providing work equipment that supports employee safety. In addition, a research replication involving a greater number of employees as well as a more varied type of work needs to be conducted. $\square$

\section{References}

Azwar, S. (2013). Penyusunan skala psikologi. Yogyakarta: Pustaka Pelajar. 
Baron, R. M., \& Kenny, D. A. (1986). The moderator-mediator variable distinction in social psychological research: Conceptual, strategic, and statistical considerations. Journal of Personality and Social Psychology, 51(6), 1173-1182. https://doi.org/10.1037/0022-3514.51.6.1173

Bird, F. E., \& Germain, G. L. (1996). Practical loss control leadership (Revised Edition). USA: DNV GL Business Assurance.

BPJS News Team. (2019, January 16). Angka kecelakaan kerja cenderung meningkat, BPJS Ketenagakerjaan bayar santunan Rp1,2 triliun. Retrieved from https://www. bpjsketenagakerjaan.go.id/berita/23322/Angka-Kecelakaan-Kerja-Cenderung-Meningkat,BPJS-Ketenagakerjaan-Bayar-Santunan-Rp1,2-Triliun

Budiono, S. (2003). Bunga rampai Hiperkes dan kesehatan kerja. Semarang: Badan Penerbit Universitas Diponegoro.

Dessler, G. (2005). Human resource management. New Jersey: Prentice-Hall.

Griffin, M., Neal, A., \& Neale, M. (2000). The contribution of task performance and contextual performance to effectiveness: Investigating the role of situational constraints. Applied Psychology, 49(3), 517-533. https://doi.org/10.1111/1464-0597.00029

Heinrich, H. W. (1980). Industrial accident prevention. (D. Petersen \& N. R. Roos, Eds.) (5th ed.). New York: McGraw-Hill.

Hofmann, D. A., \& Stetzer, A. (1996). A cross-level investigation of factors influencing unsafe behaviors and accidents. Personnel Psychology, 49(2), 307-339. https://doi.org/10.1111/j.17446570.1996.tb01802.x

Huda, U. F., Sukmawati, A., \& Sumertajaya, I. M. (2016). Model perilaku keselamatan kerja karyawan pada industri berisiko tinggi. Jurnal Manajemen Teknologi, 15(1), 51-66. https://doi.org/ 10.12695/jmt.2016.15.1.4

Kavianian, H. R., \& Wentz, C. A. (1990). Occupational and environmental safety engineering and management. New York: Van Nostrand Reinhold.

Lingard, H. (2002). The effect of first aid training on Australian construction workers' occupational health and safety motivation and risk control behavior. Journal of Safety Research, 33(2), 209230. https://doi.org/10.1016/S0022-4375(02)00013-0

Neal, A., \& Griffin, M. A. (2002). Safety climate and safety behaviour. Australian Journal of Management, 27(1), 67-75. https://doi.org/10.1177/031289620202701S08

Neal, A., \& Griffin, M. A. (2006). A study of the lagged relationships among safety climate, safety motivation, safety behavior, and accidents at the individual and group levels. Journal of Applied Psychology, 91(4), 946-953. https://doi.org/10.1037/0021-9010.91.4.946

Ningsih, A. R., \& Wahyudiono, Y. D. A. (2013). Evaluasi pelaksanaan behavior based safety pada program stop dalam membentuk perilaku aman tenaga kerja di pt $\mathrm{x}$ tahun 2013. The Indonesian Journal of Occupational Safety and Health, 2(1), 35-44.

Probst, T. M., \& Brubaker, T. L. (2001). The effects of job insecurity on employee safety outcomes: Crosssectional and longitudinal explorations. Journal of Occupational Health Psychology, 6(2), 139159. https://doi.org/10.1037/1076-8998.6.2.139

Safety Sign Indonesia. (2015, May 25). Setiap 15 detik, 1 pekerja di dunia meninggal akibat kecelakaan kerja. Safety Sign Indonesia. Retrieved from https://www.safetysign.co.id/news/154/Setiap15-Detik-1-Pekerja-di-Dunia-Meninggal-Akibat-Kecelakaan-Kerja 
Setiawan, M. A., \& Agustina, T. S. (2014). Pengaruh safety climate terhadap kecelakaan kerja dengan safety behavior sebagai variabel intervening pada karyawan PT Panca Wana Indonesia di Krian. Jurnal Manajemen Teori dan Terapan, 7(2), 125-136. https://doi.org/10.20473/ JMTT.V7I2.2706

Snyder, L. A., Krauss, A. D., Chen, P. Y., Finlinson, S., \& Huang, Y.-H. (2008). Occupational safety: Application of the job demand-control-support model. Accident Analysis \& Prevention, 40(5), 1713-1723. https://doi.org/10.1016/j.aap.2008.06.008

Sujadiyanto, R. G. (2017). Komitmen afektif sebagai mediator dalam hubungan antara persepsi dukungan organisasi (POS) dan safety behavior pada karyawan departemen operasional PT Pusri Palembang. Undergraduate thesis. Universitas Sanata Dharma, Yogyakarta.

Sulistiobudi, R. A., \& Kadiyono, A. L. (2017). Menumbuhkan keterlibatan positif dalam bekerja: Melalui iklim kompetisi ataukah pengembangan kompetensi? Psikohumaniora: Jurnal Penelitian Psikologi, 2(1), 60-80. https://doi.org/10.21580/pjpp.v2i1.1273

Taqwa, K. Z. (2017). Hubungan antara safety climate dengan safety behavior pada karyawan departemen produksi PT Pura Barutama Unit Offset Kudus. Undergraduate thesis. Universitas Negeri Semarang, Semarang.

Vinodkumar, M. N., \& Bhasi, M. (2010). Safety management practices and safety behaviour: Assessing the mediating role of safety knowledge and motivation. Accident Analysis \& Prevention, 42(6), 2082-2093. https://doi.org/10.1016/j.aap.2010.06.021

Vitri, R. S. (2003). Hubungan antara dukungan supervisor (supervisor support) dan dukungan rekan kerja (coworker support) dengan motivasi keselamatan (safety motivation). Undergraduate thesis. Universitas Surabaya, Surabaya.

Winarsunu, T. (2008). Psikologi keselamatan kerja. Malang: UPT Penerbitan Universitas Muhammadiyah Malang.

Zohar, D. (2003). Safety climate: Conceptual and measurement issues. In J. C. Quick \& L. E. Tetrick (Eds.), Handbook of occupational health psychology. (pp. 123-142). Washington: American Psychological Association. https://doi.org/10.1037/10474-006 